\title{
LABORATORY DIAGNOSTICS AS A BASIS FOR 5P MEDICINE
}

Shcherbo SN $\bowtie$, Shcherbo DS

Pirogov Russian National Research Medical University, Moscow, Russia

As public health systems are being modernized across the world, conventional medicine is undergoing a serious transformation and new medical models are emerging based on personalized, predictive, preventive, participatory, precision, mobile, and digital approaches. So far, there is no consensus in the literature and the medical community about the goals, objectives and applications of these models, particularly precision medicine, which is sometimes perceived as merely a fancier term for personalized medicine. The role of laboratory diagnostics in precision medicine is also a matter of intense debate. This review analyzes the currently available information about precision medicine and gives examples of how 5P approaches can be used in clinical practice.

Keywords: medicine 5P, clinical laboratory diagnostics, precision medicine, cancer, diabetes mellitus

$\bowtie$ Correspondence should be addressed: Sergey N. Shcherbo

Ostrovityanova 1, Moscow, 117997; shcherbos@mail.ru

Received: 30.01.2019 Accepted: 13.02.2019 Published online: 14.02.2019

DOI: $10.24075 / \mathrm{brsmu} .2018 .095$

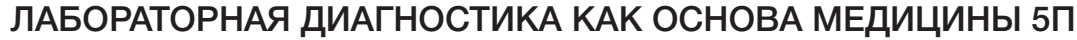

\author{
С. Н. Щербо $\bowtie$, Д. С. Щербо
}

Российский национальный исследовательский медицинский университет имени Н. И. Пирогова, Москва, Россия

В рамках модернизации системы здравоохранения в настоящее время происходят изменение старых и становление новых направлений современной медицины: персонализированной, предиктивной, превентивной, партисипативной, прецизионной, мобильной и цифровой. Вместе с тем, в научной литературе и медицинском сообществе имеются различные мнения о целях, области применения и задачах указанных направлений здравоохранения и роли в них лабораторной диагностики. Прежде всего это относится к прецизионной медицине, которая воспринимается только как более современное название персонализированной медицины. В обзоре проанализирована и обобщена имеющаяся на сегодняшний день информация и представлены примеры применения подходов медицины 5П в клинической практике.

Ключевые слова: медицина 5П, клиническая лабораторная диагностика, прецизионная медицина, онкология, сахарный диабет

$\triangle$ Для корреспонденции: Сергей Николаевич Щербо

ул. Островитянова, д. 1, г. Москва, 117997; shcherbos@mail.ru

Статья получена: 30.01.2019 Статья принята к печати: 13.02.2019 Опубликована онлайн: 14.02.2019

DOI: $10.24075 /$ vrgmu.2018.095

As the new wave of innovations driven by powerful technologies heralds a shift in the scientific paradigm expected to reach its maturity in the 2040s, we are witnessing the fast-paced evolution of nature and the human society. In these times of rapid progress, it is becoming crucial to identify major healthcare trends and to assess their potential. It is important to understand how conventional medical approaches and the medicine of the future will co-exist and interact. In 2015, the authors of this article proposed a concept of $5 \mathrm{P}$ medicine $[1,2]$ based on the analysis of the evolution of medicine and biology in the preceding 10 years. The concept was inspired by the precision medicine initiative that was intended to cover a wide range of public health aspects and to integrate genomic breakthroughs with the achievements of the communication revolution, cellular medicine and omics technologies (such as diagnostic panels of biomarkers measured at different levels of biological organization). Precision medicine approaches are mindful of the shifts in philosophical beliefs, ethical norms and the economic situation in a society. The long-reigning medical paternalism is now giving way to participatory medicine that encourages active interaction between the doctor and the patient. The concept of 5P medicine emerged in the wake of failed expectations imposed on genome-wide association studies (one of their challenges being the missing heritability problem) and reflects the current state of the medical and biological sciences. At the moment, there is some confusion about the terms describing the components of 5PM, their relationships and the directions 5PM may take. Will the medicine of the future be 4P (predictive, preventive, participatory, and personalized) or $5 \mathrm{P}$, introducing precision medicine as the $5^{\text {th }}$ component? Failure to understand the fundamental principles and objectives of precision medicine may lead to it being perceived as merely a fancier term for personalized medicine [3]. Although each of the components constituting 5P medicine certainly has a value of its own, together they complement and reinforce each other (hence the term "predictive preventive medicine"). The adoption of the 5PM concept allows us to clearly delineate the goals and objectives of contemporary medicine. This is particularly important in educating and training medical staff. Previously, we showed that the evolution of laboratory medicine would take the direction determined by the goals of emerging healthcare areas. Depending on the objective, laboratory medicine can deal with different types and arrays (panels) of biomarkers at different levels of biological organization [4-6].

\section{Predictive medicine}

The problems of early diagnosis, prognostication and assessment of risks for developing a pathology constitute one of the most promising areas of contemporary molecular medicine that relies on laboratory diagnostics. Preventive medicine makes predictions about the probability of a certain disease based on a patient's data, including the results of omics tests. The Nobel laureate Jean Dausset (1980) who proposed the term "predictive" commented that prevention is the main goal of the medical science. He realized it after discovering associations between the alleles of the HLA genetic locus and a few multifactorial diseases (diabetes mellitus, bronchial asthma, etc.). Predictive medicine seeks to notice change in patients' general health before they develop clinical symptoms. It is a diagnostic branch of medicine that exploits laboratory 
and functional tests, various imaging modalities, bioinformatics, etc. Disease prediction can be aided by genetic testing, which has been instrumental in discovering genetic predisposition to somatic and infectious diseases (TB, viral hepatitis, HIV, etc.). Preventive testing involves identification of the hallmarks of pathogenesis. For example, Michael Snyder carried out a laborious expensive experiment allowing him to catch the onset of diabetes signaled by abrupt changes in the levels of biomarkers that had never been linked to diabetes before [7]. Using omics technologies, Snyder was able to obtain a highly accurate integrative personal omics profile (iPOP) containing information about his genomic sequence, blood biochemistry, and the levels of mRNA, proteins and other biomolecules measured repeatedly (20 times) over the course of 14 months. The experiment yielded a database of 3 billion records in total. At present, exhaustive iPOP-profiling is not available for the majority of patients. However, smaller profiles built from dozens of the most informative parameters instead of hundreds of thousands can still be very useful. It's unrealistic to believe that a healthy individual will be eager to give their blood for tests every hour or pay frequent visits to a doctor's office for a checkup. Therefore, we need rapid and cost-effective methods for studying biological specimens. For example, instead of proteomic testing, which lasts for 30 to 200 minutes, one can analyze protein metabolites; the latter can be measured in as little as 30 seconds. A team of researchers has tested the ability of whole-genome sequencing to predict the risk of 24 relatively prevalent diseases. Based on the sequencing data, they were able to predict predisposition to at least one disease in the majority of patients [8]. Contemporary medicine has embraced the importance of early diagnosis, which improves treatment outcomes and reduces its costs. The use of highly sensitive and highly specific diagnostic tools is vital for early diagnosis. So are regular medical examinations and checkups.

\section{Preventive medicine}

Preventive care (from French préventif) is a branch of medicine that aims to delay the onset of a disease, mitigate its severity or treat its first manifestations, such as unhealthy weight gain, decline in physical activity, etc. The National Institutes of Health (USA) describe preventive care as one of 5 prioritized areas of medicine that needs to be actively supported and developed in order to provide customized care for patients aiming to improve their quality of life and extending the life span to its natural limits.

\section{Participatory (patient-oriented) medicine}

As the name suggests, participatory medicine encourages a patient to be involved in the medical process and actively interact with their doctor. Participatory medicine is intimately related to predicative and preventive medicine and draws on philosophy, deontology and psychology. Cooperation and sympathy have always played a crucial role in the doctor-patient relationship. A physician and writer Abu'l Faraj who lived in the $13^{\text {th }}$ century appealed to his patient: "There are 3 of us here: you, the illness and myself. If you join the illness, the two of you will overpower me. If you join me instead, the illness will have no one to turn to, and together we will defeat it". However, it was not until the $16^{\text {th }}$ and $17^{\text {th }}$ centuries that European physicians, such as John Gregory and Thomas Percival, started to admit that a patient has a right to voice their own opinion about the medical process. The legal term "informed consent" dates back to 1957. Even today, there are situations when full informed consent cannot be obtained, as is the case with unconscious patients. But under any circumstances, a doctor should treat their patients with respect and not look down on them. The patient has a right to ask questions and make their own choice. Unfortunately, treatment guidelines and standards of care formulated by expert organizations unintentionally become the source of medical paternalism, although it is stressed that they should not be followed blindly and individual characteristics of a patient should be taken into account. In the not so distant past, a patient had no access to their medical records made during a short physical examination, and the doctor-patient interaction was best described as silent [9]. In contrast, participatory medicine recognizes that a patient knows his/her body better than anyone else and is interested in maintaining good health; therefore, the patient should actively participate in generating the vast array of medical data related to their health. These data originate from a medical history, diagnostic images, instrumental readings, results of omics and other types of tests. Integrated medical records will soon be available to patients via cloud database services, a supercomputer or telemedically. The state-of-the-art technologies allows patients to obtain health-related information on internet forums or in expert internet communities, from mobile applications, including medication reminder apps, electronic diaries, and medical devices for self-testing. Thus, the accumulated information will be communicated between the doctor and the patient.

\section{Personalized medicine}

The term "personalized medicine" (PM) was first used in 1998 [10]. Sometimes, PM is defined as pharmacogenomics (genomic medicine, genotype-based therapy, customized healthcare, information-based medicine, integrated healthcare, rational prescribing, etc. [2]). The Personalized Medicine Coalition (Washington, USA) stresses that PM uses "new methods of molecular analysis to better manage a patient's disease or predisposition toward a disease. It aims to achieve optimal medical outcomes by helping physicians and patients choose the disease management approaches likely to work best in the context of a patient's genetic and environmental profile" [11]. Hopes are high that personalized medicine will improve the quality of healthcare services and significantly reduce their costs. US Food and Drug Administration (FDA) sees PM as an arsenal of therapeutic techniques that "consider a patient's genetic, anatomical, and physiological characteristics" providing "the right patient with the right drug at the right dose at the right time" [12]. PM can also be regarded as a novel healthcare model that exploits diagnostic, prevention, and therapeutic tools that are economically or ethically feasible for a given patient and best cater to their needs. PM objectives include elucidating molecular mechanisms underlying a pathology, identifying its most important biomarkers, and designing personalized therapeutic drugs (TD) that can effectively modify or eliminate the targets associated with pathology [13]. PM attempts to categorize pathogenetic mechanisms associated with the development of a disease into types and subtypes (here, cancer research is a good example); it looks for effective therapeutic targets and seeks to improve patient stratification. It should be born in mind that PM is a branch of healthcare that deals with diseases that have already set in and manifested themselves through clinical symptoms and signs [6]. The UNESCO International Bioethics Committee defines personalized medicine as "the tailoring of medical interventions to the specific characteristics of each patient, realized through pharmacogenomics and genotypebased treatments". The majority of experts agree that better patient stratification will produce better outcomes in terms of 
treatment efficacy and good tolerance. A team of researchers has published an analysis of 683 medical articles from PubMed containing definitions of "personalized medicine". It turned out that this term was present in 2,457 articles (at the time of publication); $60.4 \%$ of the papers issued before 2009 and devoted to the problem of treatment customization contained a definition of this term. The authors concluded that PM seeks to improve patient stratification and healthcare timing by using data on the molecular pathways of a disease and its biomarkers [14]

The balance between standardization and personalization is very important. In a man-made environment standardization has become the cornerstone of industrialization, allowing no space for differences that did not fit into the accepted model. This principle was later applied to healthcare to establish standards for drug-based therapies, surgical intervention, etc. The post-industrial society has taken a different course of development, defying standardization. The mass media are getting demassified and focus on smaller niche audiences. This process is linked to the spread of Internet. The principle of differentiation is replacing standardization. Concentration gives way to decentralization, maximization is taken over by the principle of adequate scales, etc.

The first large-scale application of PM approaches occurred in the context of blood types discovery [15]. To date, intelligent systems for decision making have been developed to help physicians select the right medication for their patients. These systems warn the doctors of the adverse effects that may occur in patients with certain genotypes, suggest conducting a pharmacogenomic test and provide accurate clinical interpretations of its results. Preemptive pharmacogenomic testing is being actively promoted across the world. A few years back, the University of Chicago launched a project that demonstrated the feasibility of pharmacogenomic testing in the clinical setting. The physicians received alerts about patients genotypes, which ultimately improved efficacy and safety of the prescribed treatments [16].

\section{Precision medicine}

The birth of precision medicine (PrM) is associated with the development of medical, biological and information technologies and frustration that invaded the scientific community in 2010 when it became clear that human genome sequencing and GWAS had not lived up to the expectations [2]. In 2012, it was proposed to give up the term "personalized medicine" that did not reflect the situation in the medical science. The term "precision medicine" first appeared in the book by C. Christensen and J. Grossman The innovator's prescription (2009) and then was adopted in the report Toward precision medicine prepared by the Institute of Medicine of the National Academy of Sciences (2011). In 2015 the National Precision Medicine Initiative was launched [17]. The initiative aimed to collect medical data from a cohort of 1,000,000 Americans and arrange them into a database [18]. Such studies are resourceconsuming [19] yet instrumental in elaborating effective treatment algorithms. Precision and personalized medicines have a lot in common. But although the term "personalized" has long been used to refer to precision medicine, the National Research Council (USA) advises against it. Among the shortterm objectives of PrM is its application in cancer research; it is hoped that in the long run precision medicine will find its way into all areas of healthcare. Biological specimens, genetic data, information about lifestyles, the environment and general health provided by the volunteers constituting the cohort can be used to study a wide range of diseases [15, 20].
Let's take a look at the potential benefits of the PrM initiative. Note that the objectives faced by 5PM are given in brackets. Under this initiative, novel approaches will be applied to protect the privacy of study participants and ensure the confidentiality of their data (this pertains to the legal aspect of participatory medicine); novel tools will be designed to build, analyze and use the vast arrays of medical data; quality of clinical trials will improve, as well as control over drug manufacturing. New opportunities will appear facilitating cooperation between researchers with different expertise, patient communities, universities, pharmaceutical companies, etc. Millions of people will be able to make their personal contribution to scientific research (participatory medicine). Among the long-term goals of the project are extensive use of genetic and other information about biological molecules in clinical routine; accurate prediction of treatment outcomes in individual patients (predictive medicine); deeper understanding of the mechanisms underlying pathology (a challenge faced by medical and biological sciences); improving approaches to prevention, diagnostics and treatment of a wide range of diseases; deep integration of electronic medical records into clinical routine to simplify access to patients' records for medical personnel.

PM and PrM share a number of tasks: they both aim to promote the use of omics technologies and targeted TD and are supposed to account for the role of external factors in treatment. Precision medicine also faces new challenges, including promotion of electronic medical records, artificial intelligence and digital databases in healthcare facilities, as well as the use of mobile applications (24/7 health monitoring, telemedicine). The evolution of PrM will contribute to a more accurate classification of pathological conditions, help to effectively distinguish between patients' subpopulations and improve clinical outcomes. Personomics is a word that is often used when it comes to discussing the objectives of PM and PrM [21]. Genomics, proteomics, metabolomics, epigenomics, pharmacogenomics, and other omics are tools exploited by both PrM and PM [2]. Personomics can be recruited by precision medicine to describe the 5P approaches. According to the principles of personomics, differences between people are not limited to biological variability, but also comprise personal traits, attitude to healthcare, activity in social media, wealth, and other unique characteristics that have a strong impact on how and when patients will react to treatment [21]. 5P medicine is a milestone in the evolution of PM and PrM, and personomics is its missing link. In fact, transition from PM to PrM is the evolution from healthcare to health caring: "What do I need to know about you as a person to give you the best care possible?" [22].

5P medicine seeks to create diagnostic and therapeutic models in which the central focus is on the variability of symptoms determined by the individual characteristics of a patient [23]. Theranostics (therapy + diagnostics) could be a handy tool for $5 \mathrm{P}$ medicine. It is a diagnostic therapy that allows tailoring a treatment strategy to an individual patient in cases when standard therapeutic options cannot be used [24]. Obviously, precision medicine dictates the need for leaders with fundamental knowledge of genomic medicine and molecular diagnostic methods (NGS, interpretation of wholegenome sequencing data) who will introduce PrM approaches into conventional healthcare [24]. It is expected that electronic records and genomic studies will contribute to the spread of $5 \mathrm{P}$ medicine. In 2007, the eMERGE network was launched. It is essentially a consortium for genomic research and discoveries that advocates the use of biorepositories connected to the 
systems of electronic medical records [25]. Development of 5PM is dependent on the efficient IT infrastructure capable of storing, maintaining and transmitting vast arrays of genomic data to facilitate their use in the treatment of individual patients and scientific research [26].

\section{Application of PrM and 5PM in diagnostics and therapy}

At present, PrM is enjoying a somewhat limited application in public healthcare. PrM approaches are popular in oncology where they are employed to treat metastatic melanoma, breast, brain and lung malignancies, and leukemia. The most ambitious PrM project was started in Germany in 2013 (the German National Cohort or GNC). It is a nation-wide long-term study planned to last 25-30 years. Another study revealed that tumor molecular panels and personal genomic profiling had limited benefits for patients with cancer in terms of prognosis or quality of life. In a randomized controlled SHIVA study [27] samples of solid tumors were collected and subjected to molecular profiling using a special algorithm; based on the obtained profiles, targeted medication therapy was selected, and then its efficacy was assessed. SHIVA demonstrated that the median progression-free survival was almost similarly low in both groups (2.3 and 2.0 months, respectively). This does not mean, though, that PrM practices should be discontinued, especially in oncology. The negative results could be explained by the heterogeneity of tumors and the ongoing evolution of their cells [28]. Tumor cells circulating in the peripheral blood hold promise for early cancer detection and liquid biopsy (monitoring of relapse in patients with colon and lung cancers); they can be used to analyze a tumor's resistance to drugs and assist selection of adequate therapy. Tumor cells, exosomes and circulating free DNA are convenient diagnostic and prognostic markers that can be measured using minimally invasive techniques [2, 29].

Prevention, screening and diagnosis of prostate cancer still poses a medical dilemma [30]. Prostate cancer is the most prevalent malignancy in men. It is a heterogenous group of pathologies with unique genetic and proteomic profiles. Molecular genotyping has helped to identify at least 7 molecular subtypes of prostate cancer that differ in their ability to metastasize [31]. According to some estimates, heritability of prostate cancer reaches $42 \%$ (95\% Cl). Genome-wide association studies have reported over 70 different SNPs that can predict the risk of this disease [32]. Genetic data, such as information about the BRCA genotype, can considerably facilitate selection of an adequate screening strategy and stop overtreatment of men at low risk for prostate cancer. Genotyping also serves to identify patients with a potentially good response to 5-alpha-reductase inhibitors, nonsteroidal anti-inflammatory drugs, selective estrogen receptor modulators, and statins [33]. PrM approaches could be beneficial for patients with benign prostatic hyperplasia [34], another heterogenous group of diseases with unique molecular profiles, varying in their growth rate and severity [35]. So far, GWAS have detected associations between certain SNPs and the risk for/severity of benign prostate hyperplasia. Knowledge of these associations opens new possibilities for stratifying patients based on the results of pharmacogenomic testing in groups at risk or those receiving treatment [36]. Better understanding of the mechanisms regulating the contractility of prostatic smooth muscles through $\alpha_{1}$-adrenergic receptors and androgen signaling expands the list of the available treatment options (in about $30 \%$ of men inhibition of $5 A R 2$ methylation is associated with resistance to finasteride).
Precision diabetes mellitus (DM) is a disease manifested as a broken balance between the body's need for insulin and the actual amount of insulin produced or the resistance to this hormone in the backdrop of normal secretion. Diabetes is triggered by many factors, including obesity. There is little doubt that in the future DM will be managed using the principles of precision medicine. The current classification of diabetes into types 1 and 2 relies on the detection of antibodies against pancreatic $\beta$-cell antigens; more than $80 \%$ of diagnosed cases are type 2 diabetes. The latter can be broken down into a number of subtypes. For example, by 2018, a few new subtypes had been described, including latent autoimmune diabetes of adults (LADA) affecting patients over 18 years of age, maturity onset diabetes of the young (MODY) striking teenagers under 18, and some others. In 2017, Swedish researchers showed that type 3c (diabetes of the exocrine pancreas) is often mistaken for type 2 DM. Studies of glutamic acid decarboxylase antibodies (GADA) and genetic polymorphisms demonstrate that DM is very diverse, and early diagnosis and therapy are crucial for minimizing its sequelae, preventing chronic complications and reducing mortality associated with this disease. Omics technologies have been very instrumental in discovering promising diabetes biomarkers, such as microRNA. This molecule is involved in insulin secretion, the growth and differentiation of pancreatic $\beta$-cells, and the regulation of glucose and lipid metabolism. It is also implicated in obesity and secondary complications of diabetes. The list of microRNA types that affect production and secretion of insulin by pancreatic $\beta$-cells includes microRNA-375, -9, -96, and $-124 a$. MicroRNA-375 of pancreatic $\beta$-cells regulates insulin secretion in response to stimulation with glucose. Specifically, its overexpression inhibits insulin secretion [2, 37].

Researchers from Lund University (Sweden) have proposed a new classification of DM in adults: instead of types 1 and 2, 5 subtypes should be distinguished. They are characterized by unique progression patterns and different risks of complications. The classification was proposed upon analyzing the data collected from 14,000 individuals. The data came from 5 different sources: the ANDIS project, which recruited more than 8, 000 participants over the course of 8 years (2008-2016), the Scania Diabetes Registry, ANDIU, Baaca (DIREVA), and the Cancer Cardiovascular Arm of Malmö Diet. The researchers analyzed the results yielded by laboratory tests, patients' age at the time of diagnosis and the first manifestations, BMI, levels of GADA, glycated haemoglobin $\mathrm{HbA} 1 \mathrm{c}$ and C-peptide, HOMA-IR, and insulin resistance. The proposed classification has a potential to become a powerful tool for tailoring treatment strategies to individual patients and for the identification of people at risk for complications. Under this classification, patients are divided into 5 clusters [38]: severe autoimmune diabetes (6-15\%) with early onset, corresponding to classic type 1 DM and LADA; severe diabetes with insulin deficiency (9-20\%) characterized by elevated $\mathrm{HbA} 1 \mathrm{c}$ levels, rapid progression of retinopathy and negative GADA; severe diabetes with insulin resistance $(11-17 \%)$ diagnosed in overweight patients with $\mathrm{BMI}>25$ (in this cluster nephropathy and retinopathy were the most prevalent); moderate diabetes associated with obesity (18$27 \%$ ) occurring in young patients with $\mathrm{BMI}>30-34$; moderate diabetes of adults (33-47\%) with moderate metabolic changes. This type occurs much later in life in comparison with other diabetes types and its course is milder. Patients with severe forms of the disease need aggressive therapy. Patients from cluster 2 are diagnosed with type $2 \mathrm{DM}$, because the disease is not autoimmune; this type is presumably caused by defective pancreatic islets and not obesity. In this case therapy must be 
based on the regimens typically prescribed to patients with type $1 \mathrm{DM}$; Such patients suffer from ocular pathology more often, while patients from group 3 tend to develop a kidney disease. This must not be overlooked when deciding on the adequate screening procedure. Perhaps, there are hundreds of diabetes subtypes in the world shaped by various genetic, ethnic or environmental factors. People of South Asian origin are at a higher risk for DM. Diabetes is diagnosed in one of 6 Native Americans and Alaskan Inuit.

Although DM is not a monogenic hereditary disease, its risk increases in children born into the families where one or more relatives already have diabetes and carry predisposition genes (HLA-DR3 and HLA-DR4 haplotypes) [39]. Type 2 DM is characterized by carbohydrate metabolism disorders caused by insulin resistance or insulin deficiency. The risk of this disease is as high as $40 \%$ if one of the parents has it, and reaches $70 \%$ if both parents are affected [40]. Type 2 DM displays a considerable variability in its progression patterns, response to treatment and the risk of complications. Type 2 is believed to be a polygenic condition with up to 20 genes involved, including those coding for the structure of insulin molecules, insulin receptors, glucokinase, glycogen synthase, and mitochondrial components. There are genes accountable for insulin resistance (PPARG, THADA, ADAMTS9, and others), $\beta$-cell dysfunction (KCNJ11, HNF1B, HNF4A, JAZF, etc.), obesity (FTO), and defective incretin hormone secretion (TCF7L2). Because insulin resistance is heterogeneous, traditional drugs, such as metmorfin or thiazolidinedione are often ineffective in patients with type 2 DM. At present, the arsenal of antidiabetes therapies includes 8 classes of glucose-lowering drugs that target different components pathogenic pathways implicated in type $2 \mathrm{DM}$. Another 5 novel drug classes are now undergoing preclinical studies. At the moment, we cannot accurately distinguish between diabetes subtypes based on their molecular etiology and have to rely on patients' response to treatment. The initial differentiation should be carried out using the available clinical data (sex, BMI, age at diagnosis) or biomarkers that are easy to measure. So far, this approach has been successfully used to identify female patients with positive response to thiazolidinedione (obesity) or sulphonylurea [41].

It took the medical community some time to recognize the MODY subtype. Genetic testing for DM will soon be available in most countries. In 2016, 5, 000 studies were conducted in the UK and clear diagnostic guidelines were proposed [42]. No sophisticated probability computations are required to assess the risk for MODY; the diagnosis can be established using a statistical calculator and the available clinical data. The MODY probability calculator is free and can be accessed at www.diabetesgenes.org and in the "Diabetes" application for IOS and Android [43]. It works best for patients who do not receive insulin. This popular calculator (> 6,000 downloads) has become an important step toward precision diabetology. It is a good example of how a complex diagnostic task can be solved using a simple tool that analyzes the available clinical data. Next generation sequencing has made genetic testing easier. But there has to be pre-screening to select patients with possible monogenic diabetes for the test. Modern technologies allow rapid and effective analysis of classic genes implicated in diabetes using a genetic panel [44] and are capable of identifying $25 \%$ of patients with monogenic diabetes caused by less popular genes.

Neurological diseases are a rewarding object for PrM application due to the rapid accumulation of genetic knowledge, extensive phenotypical classification, discovery of biomarkers, and development of potentially promising treatments [45]. A good example here is Parkinson's disease [46]. Precision psychiatry (the term was coined by Vieta et al. [47]) is one of the most advanced PrM branches [48]. The pathophysiology of neurological disorders remains understudied: the symptoms of different conditions often overlap or vary significantly between patients affected by the same disease [49]. A new approach to the classification of psychiatric disorders has been proposed that relies on neurobiological research [50]. Today, we are bestowed with an unprecedented opportunity to build vast databases from large-scale biological data that can be submitted using electronic devices (smartphones). This facilitates the analysis and allows identifying specific characteristics of an individual patient [51]. Considering that none of known biomarkers is likely to signal a psychiatric disorder on its own [52], theoretical and practical approaches to data acquisition are needed to delineate complex profiles of biomarker combinations accounting for the heterogeneity of manifestations of psychiatric diseases. It is important to recruit panomics and employ computational modeling of biological systems that could shed light on the major biological pathways involved in the development of psychiatric pathologies. Neurobiological data can be incorporated into the corresponding behavioral profiles that can be acquired using mobile technologies [53]. We believe that in the years to come, the new precision paradigm will lead to the discovery of biomarkers that can simplify decision making about a treatment strategy and predict response to the most widely used medications, such as antidepressants and antipsychotic drugs. This is already happening: C-reactive protein is exploited as a differential predictor of a patient's response to escitalopram and nortriptyline [54].

Immunotherapy is an optimal model for PrM as it describes the symptoms, functions, and molecular etiology of the disease; it can also be tailored to the needs of an individual patient [55]. Allergen immunotherapy remains one of the best candidates for the application of PM approaches. Today we understand what major immunologic and molecular events underlie the symptoms of allergies [56]. There are sensitive diagnostic tests for the detection of IgE-mediated reactions; molecules are known participating in allergic reactions; purified and standardized products are manufactured to ensure safe and effective treatment of allergies. 5PM remains a defining aspect in the treatment of "difficult and expensive" diseases, such as COPD [57] and asthma [58].

We need computational models to predict the risk of pathology for healthy people, prognosticate disease progression and design effective treatments with minimal adverse effects [59]. The "virtual patient" is one of such models based on the integration of molecular, physiological and anatomic data of humans collected under the ITFoM initiative. ITFoM is one of 6 technologies of the future funded by the European Commission. It has attracted over 150 academic and industrial partners from 34 countries. The initiative will promote the development of functional genomics and computer technologies to create a model of a virtual patient suitable for the use in the clinical setting. Genome profiles will be integrated with proteome and metabolome data generated by powerful chromatography, mass spectrometry and nuclear magnetic resonance technologies. The model will be used to analyze the current situation and predict a patient's response to therapy, including intolerance to therapeutic drugs. Successful clinical application of laboratory tests requires identification of healthy populations whose characteristics could be used as 
a reference. Organized into biorepositories, such data will play a key role in determining reference ranges needed to improve treatment outcomes.

\section{CONCLUSIONS}

5P medicine is an evolving area of public healthcare. Many of the technologies required to accomplish its ambitious goals are still in the early stages of development or yet to be designed. Researchers have to find a way to standardize collection of clinical data, create databases for the convenient storage of vast data arrays and promote biorepositories. 5PM raises important ethical, social and legal questions. Patients' privacy and confidentiality of their medical records must be protected. Patients should be informed of the risks and benefits associated with their participation in clinical studies and the use of modern 5PM technologies. This means that a procedure for obtaining informed consent has to be elaborated. The cost of the studies is another obstacle in the way of 5PM: DNA sequencing is fairly expensive, although recently its costs have been going down and tiny, flashcardsized sequencers have emerged. Perhaps, targeted therapy will still be slightly more expensive than conventional treatments, and this may pose a problem of reimbursing the expenses to state agencies and insurance companies. It is vital that 5PM approaches should become a part of routine medical care. Medical staff will learn more and more about 5P medicine and its prospects over time, and a need will arise to interpret the results of genetic and omics tests in the context of treatment and prophylaxis.

\section{References}

1. Shcherbo SN, Shcherbo DS. Medicina 5P: Precizionnaja medicina. Medicinskij alfavit. Sovremennaja laboratorija. 2015; (4): 5-10.

2. Shcherbo SN, Shcherbo DS. Personalizirovannaja medicina: monografija $\vee 7$ tomah. t. 1. Biologicheskie osnovy. Moskva. RUDN. 2016, 224 s.; t. 2. Laboratornye tehnologii. Moskva. RUDN. 2017, 437 s.

3. Raskina KV, Martynova EJu, Perfil'ev AV, i dr. Ot personalizirovanno $\mathrm{k}$ tochnoj medicine. Racional'naja farmakoterapija $\vee$ kardiologii. 2017; 13 (1): 69-79.

4. Shcherbo SN, Shcherbo DS. Medicina 5P: mobil'noe zdravoohranenie. Medicinskij alfavit. Sovremennaja laboratorija. 2017; 4 (28): 5-11.

5. Godkov MA. Laboratornaja diagnostika $v$ jepohu nauchnotehnicheskoj revoljucii. Zakat ili rassvet? Laboratornaja sluzhba. 2017; 6 (3): 5-8.

6. Shcherbo SN, Toguzov RT. Tendencii razvitija sovremennoj laboratornoj mediciny (lekcija). Klinicheskaja laboratornaja diagnostika. 2009; (3): 25-32.

7. Snyder M. iPOP and its role in participatory medicine. Genome Med. 2014; (6): 6.

8. Roberts NJ, Vogelstein JT, Parmigiani G, et al. The predictive capacity of personal genome sequencing. Sci Transl Med. 2012; 4 (133): 133 ra58

9. Katz J. The silent wold of doctor and patient. Baltimore: Johns Hopkins University Press, 1983

10. Jain KK. Personalized Medicine. Waltham: Decision Resoures Inc., MA, USA; 1998.

11. Personalized Medicine Coalition (PMC). The Case for Personalized Medicine. 2010.

12. U.S. Food and Drug Administration (FDA) Department of Health and Human Services, Paving the Way for Personalized Medicine: FDA Role in a New Era of Medical Product Development. [(accessed on 10 January 2014)]; Available from: http:// www.fda.gov/downloads/ScienceResearch/SpecialTopics/ PersonalizedMedicine/UCM372421.pdf.

13. Ginsburg GS, Willard HF. Genomic and Personalized Medicine. Elsevier Science. 2012; $1350 \mathrm{p}$.

14. Schleidgen $\mathrm{S}$, Klingler $\mathrm{C}$, Bertram $\mathrm{T}$, et al. What is personalized medicine: sharpening a vague term based on a systematic literature review. BMC Med Ethics. 2013; (14): 55.

15. Nabipour I, Assadi M. Precision medicine, an approach for development of the future medicine technologies. ISMJ. 2016; (19): 167-84

16. O'Donnell PH, Danahey K, Jacobs M. Adoption of a clinical pharmacogenomics implementation program during outpatient care - initial results of the University of Chicago «1,200 Patients Project». Am J Med Genet C Semin Med Genet. 2014; (166C): $68-75$.

17. Juengist E, McGowan ML, Fishman JR, et al. From «Personalized» to «Precision» Medicine: The Ethical and Social Implications of Rhetorical Reform in Genomic Medicine. Hastings Cent Per. 2016; 46 (5): 21-33.

18. Interlandi J. The Paradox of Precision Medicine. Sci Am. 2016; 314 (4): 24-25.

19. Joyner MJ, Paneth N. Seven Questions for Personalized Medicine. JAMA. 2015; (55905): 2015-16.

20. Collins FS, Varmus H. A New Initiative on Precision Medicine. N Engl J Med. 2015; (372): 793-95.

21. Ziegelstein RC. Personomics. JAMA Intern. Med. 2015; (175): 888-89.

22. Chochinov HM. Health care, health caring, and the culture of medicine. Curr Oncol. 2014; (21): e668-e669.

23. Gupte AA, Hamilton DJ. Molecular Imaging and Precision Medicine. Cardiology. 2016; (133): 178-80.

24. Mason-Suares $\mathrm{H}$, Sweetser $\mathrm{D}$, Lindeman $\mathrm{N}$, et al. Training the Future Leaders in Personalized Medicine. J Pers Med. 2016; 6 (1): 1.

25. Smoller J, Karlson E, Green R, et al. An eMERGE Clinical Center at Partners Personalized Medicine. J Pers Med. 2016; 6 (1): 5.

26. Hricak $\mathrm{H}$. Oncologic imaging: a guiding hand of personalized cancer care. Radiology. 2011; (259): 633-40.

27. Le Tourneau C, Delord JP, Gonçalves A, et al. Molecularly targeted therapy based on tumour molecular profiling versus conventional therapy for advanced cancer (SHIVA): a multicentre, open-label, proof-of-concept, randomised, controlled phase 2 trial. Lancet Oncol. 2015; (16): 1324-34.

28. Garraway LA, Verweij J, Ballman KV. Precision oncology: an overview. J Clin Oncol. 2013; 31 (15): 1803-05.

29. Bettegowda C, Sausen M, Leary R.J, et al. Detection of circulating tumor DNA in early- and late-stage human malignancies. Sci Transl Med. 2014; (6): 224ra24.

30. Malvezzi M, Bertuccio P, Levi F, et al. European cancer mortality predictions for the year 2014. Annals of Oncology. 2014; (25): 1650-56.

31. Attard G, Beltran $\mathrm{H}$. Prioritizing precision medicine for prostate cancer. Annals of Oncology. 2015; (26): 1041-42.

32. Amin Al, Olama A, Benlloch $\mathrm{S}$, et al. Risk analysis of prostate cancer in PRACTICAL, a multinational consortium, using 25 known prostate cancer susceptibility loci. Cancer Epidemiology, Biomarkers \& Prevention. 2015; (24): 1121-29.

33. Bancroft EK, Page EC, Castro E, et al. Targeted prostate cancer screening in BRCA1 and BRCA2 mutation carriers: Results from the initial screening round of the IMPACT study. European Urology. 2014; (66): 489-99.

34. Bechis SK, Otsetov AG, Ge R, et al. Age and obesity promote methylation and suppression of 5-alpha reductase 2-Implications for personalized therapy in benign prostatic hyperplasia. Journal of Urology. 2015; (194): 1031-37.

35. Prakash K, Pirozzi G, Elashoff $M$, et al Symptomatic and 
asymptomatic benign prostatic hyperplasia: Molecular differentiation by using microarrays. Proceedings of the National Academy of Sciences of the United States of America. 2002; (99): 7598-603.

36. Helfand BT, Hu Q, Loeb S, et al. Genetic sequence variants are associated with severity of lower urinary tract symptoms and prostate cancer susceptibility. Journal of Urology. 2013; (189): 845-48.

37. Tofilo MA, Egorova EN. MikroRNK, regulirujushhie adipogenez pri saharnom diabete 2-go tipa. Zdorov'e i obrazovanie v XXI veke. 2017; 19 (3): 108-11.

38. Ahlqvist E, Storm P, Karajamaki A, et al. Novel subgroups of adult-onset diabetes and their association with outcomes: a data-driven cluster analysis of six variables. The Lancet Diabetes Endocrinology. 2018; 6 (5): 361-69.

39. Dedov II, Titovich EV, Kuraeva TL, i dr. Vzaimosvjaz' geneticheskih i immunologicheskih markerov u rodstvennikov bol'nyh SD 1 tipa. Saharnyj diabet. 2008; (4): 46-50.

40. Meigs JB, Cupples LA, Wilson PW. Parental transmission of type 2 diabetes: the Framingham Offspring study. Diabetes. 2000; (49): 2201-17.

41. Shields BM, Longergan M, Dennis J, et al. Patient characteristics are associated with treatment response to second line glucose lowering therapy: a MASTERMIND study abstracts of 51st EASD annual meeting. Diabetologia. 2015; 58 (Suppl 1): S405.

42. Chakera AJ, Steele AM, Gloyn AL, et al. Recognition and management of individuals with hyperglycemia because of a heterozygous glucokinase mutation. Diabetes Care. 2015; (38) 1383-92.

43. Shields BM, McDonald TJ, Ellard S, et al. The development and validation of a clinical prediction model to determine the probability of MODY in patients with young-onset diabetes. Diabetologia. 2012; (55): 1265-72.

44. Pearson ER, Pruhova S, Tack CJ, et al. Molecular genetics and phenotypic characteristics of MODY caused by hepatocyte nuclear factor 4alpha mutations in a large European collection. Diabetologia. 2005; (48): 878-85.

45. Tan Lin, Jiang T, Tan Lan, et al. Toward precision medicine in neurological diseases. Ann Transl Med. 2016; 4. (6): 104.
46. Bu L-L, Yang K, Xiong W.-X, et al. Toward precision medicine in Parkinson s disease. Ann Transl Med. 2016; 4 (2): 26.

47. Vieta E. Personalised medicine applied to mental health: Precision psychiatry. Rev Psiquiatr Salud Ment. 2015; 8 (3): 117-18.

48. Fernandes BS, Williams LM, Steiner J, et al. The new field of "precision psychiatry". BMC Med. 2017; (15): 80.

49. Stephan KE, Bach DR, Fletcher PC, et al. Charting the landscape of priority problems in psychiatry, part 1: classification and diagnosis. Lancet Psychiatry. 2016; 3 (1): 77-83.

50. Insel TR. The NIMH Research Domain Criteria (RDoC) Project: precision medicine for psychiatry. Am J Psychiatry. 2014; 171 (4): 395-7.

51. Andersson G, Titov N. Advantages and limitations of Internetbased interventions for common mental disorders. World Psychiatry. 2014; 13 (1): 4-11.

52. Carvalho AF, Kohler CA, Brunoni AR, et al. Bias in peripheral depression biomarkers. Psychother Psychosom. 2016; 85 (2): 81-90.

53. Marzano L, Bardill A, Fields B, et al. The application of mHealth to mental health: opportunities and challenges. Lancet Psychiatry. 2015; 2 (10): 9442-48.

54. Uher R, Tansey KE, Dew T, et al. An inflammatory biomarker as a differential predictor of outcome of depression treatment with escitalopram and nortriptyline. Am J Psychiatry. 2014; 171 (12): 1278-86.

55. Passalaqua G, Canonica GW. AIT (allergen immunotherapy): a model for the "precision medicine". Clin Mol Allergy. 2015; (1): 24.

56. Akdis CA, Akdis M. Mechanisms of allergen-specific immunotherapy and immune tolerance to allergens. World Allergy Organ J. 2015; 8 (1): 17

57. Agusti $\mathrm{A}$. The path to personalised medicine in COPD. Thorax. 2014; (69): 857-64

58. Fajt ML, Wenzel SE. Asthma phenotypes and the use of biologic medications in asthma and allergic disease: the next steps toward personalized care. J Allergy Clin Immunol. 2015; (135): 299-310.

59. Zazzu V, Regierer B, Kuhn A, et al. IT Future of Medicine: from molecular analysis to clinical diagnosis and improved treatment. N Biotechnol. 2013; 30 (4): 362-65.

\section{Литература}

1. Щербо С. Н., Щербо Д. С. Медицина 5П: Прецизионная медицина. Медицинский алфавит. Современная лаборатория. 2015; (4): 5-10.

2. Щербо С. Н., Щербо Д. С. Персонализированная медицина: монография в 7 томах. т. 1. Биологические основы. Москва РУДН. 2016, 224 с.; т. 2. Лабораторные технологии. Москва. РУДН. 2017, 437 с.

3. Раскина К. В., Мартынова Е. Ю., Перфильев А. В. и др. От персонализированной к точной медицине. Рациональная фармакотерапия в кардиологии. 2017; 13 (1): 69-79.

4. Щербо С. Н., Щербо Д. С. Медицина 5П: мобильное здравоохранение. Медицинский алфавит. Современная лаборатория. 2017; 4 (28): 5-11.

5. Годков М. А. Лабораторная диагностика в эпоху научнотехнической революции. Закат или рассвет? Лабораторная служба. 2017; 6 (3): 5-8.

6. Щербо С. Н., Тогузов Р. Т. Тенденции развития современной лабораторной медицины (лекция). Клиническая лабораторная диагностика. 2009; (3): 25-32.

7. Snyder M. iPOP and its role in participatory medicine. Genome Med. 2014; (6): 6.

8. Roberts NJ, Vogelstein JT, Parmigiani G, et al. The predictive capacity of personal genome sequencing. Sci Transl Med. 2012; 4 (133): 133ra58.

9. Katz J. The silent wold of doctor and patient. Baltimore: Johns Hopkins University Press, 1983.

10. Jain KK. Personalized Medicine. Waltham: Decision Resoures Inc., MA, USA; 1998.
11. Personalized Medicine Coalition (PMC). The Case for Personalized Medicine. 2010.

12. U.S. Food and Drug Administration (FDA) Department of Health and Human Services, Paving the Way for Personalized Medicine: FDA Role in a New Era of Medical Product Development. [(accessed on 10 January 2014)]; Available from: http:// www.fda.gov/downloads/ScienceResearch/SpecialTopics/ PersonalizedMedicine/UCM372421.pdf.

13. Ginsburg GS, Willard HF. Genomic and Personalized Medicine. Elsevier Science. 2012; 1350 p.

14. Schleidgen $\mathrm{S}$, Klingler $\mathrm{C}$, Bertram $\mathrm{T}$, et al. What is personalized medicine: sharpening a vague term based on a systematic literature review. BMC Med Ethics. 2013; (14): 55.

15. Nabipour I, Assadi M. Precision medicine, an approach for development of the future medicine technologies. ISMJ. 2016; (19): 167-84.

16. O'Donnell PH, Danahey $\mathrm{K}$, Jacobs M. Adoption of a clinical pharmacogenomics implementation program during outpatient care - initial results of the University of Chicago «1,200 Patients Project». Am J Med Genet C Semin Med Genet. 2014; (166C): 68-75.

17. Juengist E, McGowan ML, Fishman JR, et al. From «Personalized» to «Precision» Medicine: The Ethical and Social Implications of Rhetorical Reform in Genomic Medicine. Hastings Cent Per. 2016; 46 (5): 21-33.

18. Interlandi J. The Paradox of Precision Medicine. Sci Am. 2016; 314 (4): 24-25

19. Joyner MJ, Paneth N. Seven Questions for Personalized Medicine. 
JAMA. 2015; (55905): 2015-16.

20. Collins FS, Varmus H. A New Initiative on Precision Medicine. N Engl J Med. 2015; (372): 793-95.

21. Ziegelstein RC. Personomics. JAMA Intern. Med. 2015; (175): 888-89.

22. Chochinov HM. Health care, health caring, and the culture of medicine. Curr Oncol. 2014; (21): e668-e669.

23. Gupte AA, Hamilton DJ. Molecular Imaging and Precision Medicine. Cardiology. 2016; (133): 178-80.

24. Mason-Suares $\mathrm{H}$, Sweetser $\mathrm{D}$, Lindeman $\mathrm{N}$, et al. Training the Future Leaders in Personalized Medicine. J Pers Med. 2016; 6 (1): 1.

25. Smoller J, Karlson E, Green R, et al. An eMERGE Clinical Center at Partners Personalized Medicine. J Pers Med. 2016; 6 (1): 5.

26. Hricak $\mathrm{H}$. Oncologic imaging: a guiding hand of personalized cancer care. Radiology. 2011; (259): 633-40.

27. Le Tourneau C, Delord JP, Gonçalves A, et al. Molecularly targeted therapy based on tumour molecular profiling versus conventional therapy for advanced cancer (SHIVA): a multicentre, open-label, proof-of-concept, randomised, controlled phase 2 trial. Lancet Oncol. 2015; (16): 1324-34.

28. Garraway LA, Verweij J, Ballman KV. Precision oncology: an overview. J Clin Oncol. 2013; 31 (15): 1803-05.

29. Bettegowda C, Sausen M, Leary R.J, et al. Detection of circulating tumor DNA in early- and late-stage human malignancies. Sci Transl Med. 2014; (6): 224 ra24.

30. Malvezzi M, Bertuccio P, Levi F, et al. European cancer mortality predictions for the year 2014. Annals of Oncology. 2014; (25): 1650-56.

31. Attard G, Beltran $\mathrm{H}$. Prioritizing precision medicine for prostate cancer. Annals of Oncology. 2015; (26): 1041-42.

32. Amin Al, Olama A, Benlloch $\mathrm{S}$, et al. Risk analysis of prostate cancer in PRACTICAL, a multinational consortium, using 25 known prostate cancer susceptibility loci. Cancer Epidemiology, Biomarkers \& Prevention. 2015; (24): 1121-29.

33. Bancroft EK, Page EC, Castro E, et al. Targeted prostate cancer screening in BRCA1 and BRCA2 mutation carriers: Results from the initial screening round of the IMPACT study. European Urology. 2014; (66): 489-99.

34. Bechis SK, Otsetov AG, Ge R, et al. Age and obesity promote methylation and suppression of 5-alpha reductase 2-Implications for personalized therapy in benign prostatic hyperplasia. Journal of Urology. 2015; (194): 1031-37.

35. Prakash K, Pirozzi G, Elashoff M, et al. Symptomatic and asymptomatic benign prostatic hyperplasia: Molecular differentiation by using microarrays. Proceedings of the National Academy of Sciences of the United States of America. 2002; (99): 7598-603.

36. Helfand $\mathrm{BT}, \mathrm{Hu} \mathrm{Q}$, Loeb $\mathrm{S}$, et al. Genetic sequence variants are associated with severity of lower urinary tract symptoms and prostate cancer susceptibility. Journal of Urology. 2013; (189): 845-48.

37. Тосило М. А., Егорова Е. Н. МикроРНК, регулирующие адипогенез при сахарном диабете 2-го типа. Здоровье и образование в XXI веке. 2017; 19 (3): 108-11.

38. Ahlqvist E, Storm P, Karajamaki A, et al. Novel subgroups of adult-onset diabetes and their association with outcomes: a data-driven cluster analysis of six variables. The Lancet Diabetes Endocrinology. 2018; 6 (5): 361-69.

39. Дедов И. И., Титович Е. В., Кураева Т. Л. и др. Взаимосвязь генетических и иммунологических маркеров у родственников больных СД 1 типа. Сахарный диабет. 2008; (4): 46-50.
40. Meigs JB, Cupples LA, Wilson PW. Parental transmission of type 2 diabetes: the Framingham Offspring study. Diabetes. 2000; (49): 2201-17.

41. Shields BM, Longergan M, Dennis J, et al. Patient characteristics are associated with treatment response to second line glucose lowering therapy: a MASTERMIND study abstracts of 51st EASD annual meeting. Diabetologia. 2015; 58 (Suppl 1): S405.

42. Chakera AJ, Steele AM, Gloyn AL, et al. Recognition and management of individuals with hyperglycemia because of a heterozygous glucokinase mutation. Diabetes Care. 2015; (38): 1383-92.

43. Shields BM, McDonald TJ, Ellard S, et al. The development and validation of a clinical prediction model to determine the probability of MODY in patients with young-onset diabetes. Diabetologia. 2012; (55): 1265-72.

44. Pearson ER, Pruhova S, Tack CJ, et al. Molecular genetics and phenotypic characteristics of MODY caused by hepatocyte nuclear factor 4alpha mutations in a large European collection. Diabetologia. 2005; (48): 878-85.

45. Tan Lin, Jiang T, Tan Lan, et al. Toward precision medicine in neurological diseases. Ann Transl Med. 2016; 4. (6): 104.

46. Bu L-L, Yang K, Xiong W.-X, et al. Toward precision medicine in Parkinson s disease. Ann Transl Med. 2016; 4 (2): 26.

47. Vieta E. Personalised medicine applied to mental health: Precision psychiatry. Rev Psiquiatr Salud Ment. 2015; 8 (3): 117-18.

48. Fernandes BS, Williams LM, Steiner J, et al. The new field of "precision psychiatry". BMC Med. 2017; (15): 80.

49. Stephan KE, Bach DR, Fletcher PC, et al. Charting the landscape of priority problems in psychiatry, part 1: classification and diagnosis. Lancet Psychiatry. 2016; 3 (1): 77-83.

50. Insel TR. The NIMH Research Domain Criteria (RDoC) Project: precision medicine for psychiatry. Am J Psychiatry. 2014; 171 (4): 395-7.

51. Andersson G, Titov N. Advantages and limitations of Internetbased interventions for common mental disorders. World Psychiatry. 2014; 13 (1): 4-11.

52. Carvalho AF, Kohler CA, Brunoni AR, et al. Bias in peripheral depression biomarkers. Psychother Psychosom. 2016; 85 (2) 81-90.

53. Marzano L, Bardill A, Fields $B$, et al. The application of mHealth to mental health: opportunities and challenges. Lancet Psychiatry. 2015; 2 (10): 9442-48

54. Uher R, Tansey KE, Dew $T$, et al. An inflammatory biomarker as a differential predictor of outcome of depression treatment with escitalopram and nortriptyline. Am J Psychiatry. 2014; 171 (12): 1278-86.

55. Passalaqua G, Canonica GW. AIT (allergen immunotherapy): a model for the "precision medicine". Clin Mol Allergy. 2015; (1): 24.

56. Akdis CA, Akdis M. Mechanisms of allergen-specific immunotherapy and immune tolerance to allergens. World Allergy Organ J. 2015; 8 (1): 17

57. Agusti A. The path to personalised medicine in COPD. Thorax. 2014; (69): 857-64.

58. Fajt ML, Wenzel SE. Asthma phenotypes and the use of biologic medications in asthma and allergic disease: the next steps toward personalized care. J Allergy Clin Immunol. 2015; (135): 299-310.

59. Zazzu V, Regierer B, Kuhn A, et al. IT Future of Medicine: from molecular analysis to clinical diagnosis and improved treatment. N Biotechnol. 2013; 30 (4): 362-65. 